\title{
Increased physiological dead space in mechanically ventilated COVID-19 patients recovering from severe acute respiratory distress syndrome: a case report
}

\author{
Jingen Xia ${ }^{1,2}$, Yingying Feng ${ }^{1}$, Min Li $i^{1}$, Xin Y ${ }^{1}$, Yi Zhang ${ }^{1}$, Jun Duan ${ }^{3}$ and Qingyuan Zhan ${ }^{1 *}$ (D)
}

\begin{abstract}
Background: An ongoing outbreak of coronavirus disease 2019 (COVID-19) is spreading globally. Recently, several articles have mentioned that the early acute respiratory distress syndrome (ARDS) caused by COVID-19 significantly differ from those of ARDS due to other causes. Actually, we newly observed that some mechanically ventilated COVID-19 patients recovering from severe ARDS (more than 14 days after invasive ventilation) often experienced evidently gradual increases in $\mathrm{CO}_{2}$ retention and minute ventilation. However, the underlying mechanics remain unclear.
\end{abstract}

Case presentation: To explain these pathophysiological features and discuss the ventilatory strategy during the late phase of severe ARDS in COVID-19 patients, we first used a metabolic module on a General Electric R860 ventilator (Engstrom Carestation; GE Healthcare, USA) to monitor parameters related to gas metabolism, lung mechanics and physiological dead space in two COVID-19 patients. We found that remarkably decreased ventilatory efficiency (e.g., the ratio of dead space to tidal volume $70-80 \%$, arterial to end-tidal $\mathrm{CO}_{2}$ difference $18-23 \mathrm{mmHg}$ and ventilatory ratio 3-4) and hypermetabolism (oxygen consumption 300-400 ml/min, $\mathrm{CO}_{2}$ elimination 200-300 $\mathrm{ml} / \mathrm{min}$ ) may explain why these patients experienced more severe respiratory distress and $\mathrm{CO}_{2}$ retention in the late phase of ARDS caused by COVID-19.

Conclusion: During the recovery period of ARDS among mechanically-ventilated COVID-19 patients, attention should be paid to the monitoring of physiological dead space and metabolism. Tidal volume $(8-9 \mathrm{ml} / \mathrm{kg})$ could be increased appropriately under the limited plateau pressure; however, barotrauma should still be kept in mind.

Keywords: Coronavirus disease 2019, Acute respiratory distress syndrome, Dead space ventilation, Mechanical ventilation, Case report

\footnotetext{
* Correspondence: drzhanqy@163.com

'Department of Pulmonary and Critical Care Medicine, National Clinical Research Center for Respiratory Diseases, Institute of Respiratory Medicine,

Chinese Academy of Medical Sciences, China-Japan Friendship Hospital, No

2, East Yinghua Road, Chaoyang District, Beijing 100029, China

Full list of author information is available at the end of the article
}

C C The Author(s). 2020 Open Access This article is licensed under a Creative Commons Attribution 4.0 International License, which permits use, sharing, adaptation, distribution and reproduction in any medium or format, as long as you give appropriate credit to the original author(s) and the source, provide a link to the Creative Commons licence, and indicate if changes were made. The images or other third party material in this article are included in the article's Creative Commons. licence, unless indicated otherwise in a credit line to the material. If material is not included in the article's Creative Commons licence and your intended use is not permitted by statutory regulation or exceeds the permitted use, you will need to obtain permission directly from the copyright holder. To view a copy of this licence, visit http://creativecommons.org/licenses/by/4.0/ The Creative Commons Public Domain Dedication waiver (http://creativecommons.org/publicdomain/zero/1.0/) applies to the data made available in this article, unless otherwise stated in a credit line to the data. 


\section{Background}

An ongoing outbreak of coronavirus disease 2019 (COVID-19) is spreading globally [1, 2]. As of April 29,2020 , the number of total confirmed cases has exceeded 3 million, associated to 207,973 deaths worldwide [1]. Recently, several articles [3-5] have reported that the early acute respiratory distress syndrome (ARDS) caused by coronavirus disease 2019 (COVID-19) significantly differ from those of ARDS due to other causes, such as mismatch between changes in respiratory mechanics and severity of impaired oxygenation [3], significantly decreased ventilation efficiency [4], and lower lung recruitability [5]. We also found that many mechanically ventilated COVID-19 patients recovering from severe ARDS experienced gradual increases in $\mathrm{CO}_{2}$ retention and minute ventilation (MV). To explain these pathophysiological features and discuss the ventilatory strategy during the late phase of severe ARDS in COVID-19 patients, we first used a metabolic module (COVX module; GE Healthcare, Helsinki, Finland) on a General Electric R860 ventilator (Engstrom Carestation; GE Healthcare, USA) to monitor parameters related to gas metabolism, end-expiratory lung volume (EELV), physiological dead space, ventilatory ratio (VR) [4], and lung mechanics in two COVID-19 patients.

\section{Case presentation}

Case 1: A 70-year-old woman (BMI, $21.5 \mathrm{~kg} / \mathrm{m}^{2}$ ) with acute respiratory failure caused by COVID-19 was transferred to Tongji Hospital (Wuhan, China) on February 26, 2020. On admission, she had severe dyspnea (respiratory rate [RR], $40 \mathrm{bpm}$ ) and acute hypoxemic respiratory failure (oxygen saturation $45 \%$ with oxygen flow $12 \mathrm{~L} / \mathrm{min}$ ) and underwent endotracheal intubation immediately. A tracheotomy was performed 6 days post-admission. She was supported in pressure control mode: inspiratory pressure $15-18 \mathrm{cmH}_{2} \mathrm{O}$ and positive end-expiratory pressure (PEEP) 6-8 $\mathrm{cmH}_{2} \mathrm{O}$. About 14 days post-admission, she experienced a gradual increase in RR (from 25 to $30-40 \mathrm{bpm}$ ), tidal volume (VT, from 410 to $480 \mathrm{ml}$ [7.6-9.1 ml/kg PBW]), and MV (from 10 to $12-15 \mathrm{~L} / \mathrm{min}$ ), accompanied by an increased $\mathrm{PaCO}_{2}$ (from 39 to $47-60 \mathrm{mmHg}$ ) and decreased oxygenation (arterial partial pressure of oxygen $[\mathrm{PaO} 2] /$ fraction of inspired oxygen [FiO2], from 127 to $74-100 \mathrm{mmHg} ; \mathrm{FiO}_{2}$, from 0.5 to 0.7$)$. On day 15 , the ventilator was changed to an $\mathrm{R} 860$ ventilator with COVX module. The following data were recorded: oxygen consumption $\left(\mathrm{VO}_{2}\right) 280 \mathrm{ml} / \mathrm{min}, \mathrm{CO}_{2}$ elimination $\left(\mathrm{VCO}_{2}\right) 175 \mathrm{ml} / \mathrm{min}$; ratio of dead space to $\mathrm{VT}$ (VD/VT) 78\%, end-tidal carbon dioxide $\left(\mathrm{ETCO}_{2}\right) 26.1$ $\mathrm{mmHg}$, arterial to end-tidal $\mathrm{CO}_{2}$ difference $\left(\mathrm{P}_{(\mathrm{a}-\mathrm{ET})} \mathrm{CO}_{2}\right)$ $22.3 \mathrm{mmHg}$, VR 3.57; EELV $1672 \mathrm{ml}$; airway resistance (R) $10.8 \mathrm{cmH}_{2} \mathrm{O} / \mathrm{L} / \mathrm{s}$, and respiratory system compliance
(Cresp) $12.5 \mathrm{ml} / \mathrm{cmH}_{2} \mathrm{O}$. Chest computed tomography (CT) revealed bilateral diffuse ground glass opacity, interstitial fibrosis, traction bronchiectasis, and a small amount of consolidation in the dependent aspects of the lungs on 2 day and 19 day after admission (Fig. 1). Forty days after admission, her lung function still did not recover from sustained hypercapnia in the treatment of Lopinavir/ritonavir, infusion of convalescent plasma, low molecular weight heparin and prone position ventilation, and was transferred to another hospital.

Case 2: A 42-year-old man (BMI, $22.9 \mathrm{~kg} / \mathrm{m}^{2}$ ) diagnosed with COVID-19 was transferred to Tongji Hospital (Wuhan, China) on March 3, 2020. Tracheal intubation and venous-venous extracorporeal membrane oxygenation (ECMO) were performed 25 and 24 days, respectively, before admission due to severe refractory ARDS. ECMO catheters were removed after 14 days of treatment due to a severe blood stream infection. However, ECMO was performed again due to bilateral pneumothorax 8 days before admission. Post-admission, he was treated with antiviral therapy, antibiotic therapy, tracheotomy (1 day post-admission), prone ventilation, and other treatments using our standard protocol. Oxygenation improved gradually, and the ECMO catheter was removed again 19 days post-admission. Over the next week, he showed a gradual increase in MV and hypercapnia. On day 26 post-admission, he was ventilated mechanically in pressure support mode: pressure support $18 \mathrm{cmH}_{2} \mathrm{O}$, PEEP $3 \mathrm{cmH}_{2} \mathrm{O}, \mathrm{FiO}_{2}$ 0.3, VT $651 \mathrm{ml}$ $(9.2 \mathrm{ml} / \mathrm{kg}), \mathrm{RR} 31 \mathrm{bpm}$, and $\mathrm{MV} 17.9 \mathrm{~L} / \mathrm{min}$. Arterial blood gas revealed the following: $\mathrm{pH} 7.463, \mathrm{PaCO}_{2} 51$ $\mathrm{mmHg}, \mathrm{PaO}_{2} \quad 80.4 \mathrm{mmHg}, \mathrm{HCO}_{3} 34.9 \mathrm{mmol} / \mathrm{L}$, and $\mathrm{PaO} 2 / \mathrm{FiO} 2268 \mathrm{mmHg}$. The following data were recorded using the COVX module: $\mathrm{VO}_{2} 401 \mathrm{ml} / \mathrm{min}$, $\mathrm{VCO}_{2} 292 \mathrm{ml} / \mathrm{min}$; VD/VT 76\%, ETCO $233.2 \mathrm{mmHg}$, $\mathrm{P}_{(\mathrm{a}-\mathrm{ET})} \mathrm{CO}_{2} 17.8 \mathrm{mmHg}, \mathrm{VR}$ 3.4; EELV $1000 \mathrm{ml} ; \mathrm{R} 7.7$ $\mathrm{cmH}_{2} \mathrm{O} / \mathrm{L} / \mathrm{s}$ and Cresp $19.6 \mathrm{ml} / \mathrm{cmH}_{2} \mathrm{O}$. Chest CT showed bilateral ground glass opacity, interstitial fibrosis, and traction bronchiectasis 11 days and 23 days postadmission (Fig. 1). He was disconnected from invasive ventilator and transferred to another hospital for further pulmonary rehabilitation on 38 days post-admission.

\section{Discussion and conclusion}

We found that the lung tissue of COVID-19 patients recovering from severe ARDS not only reflects the typical characteristics of late-phase ARDS (reduced lung compliance, pulmonary fibrosis, and decreased EELV) but is also associated with a significantly increased dead space (VD/VT 70-80\%, VR 3-4), markedly higher than that in patients with severe ARDS due to other reasons [6]. Besides, some COVID-19 patients show an obvious hypermetabolic status even in the recovery period. Therefore, significantly decreased ventilation efficiency and 

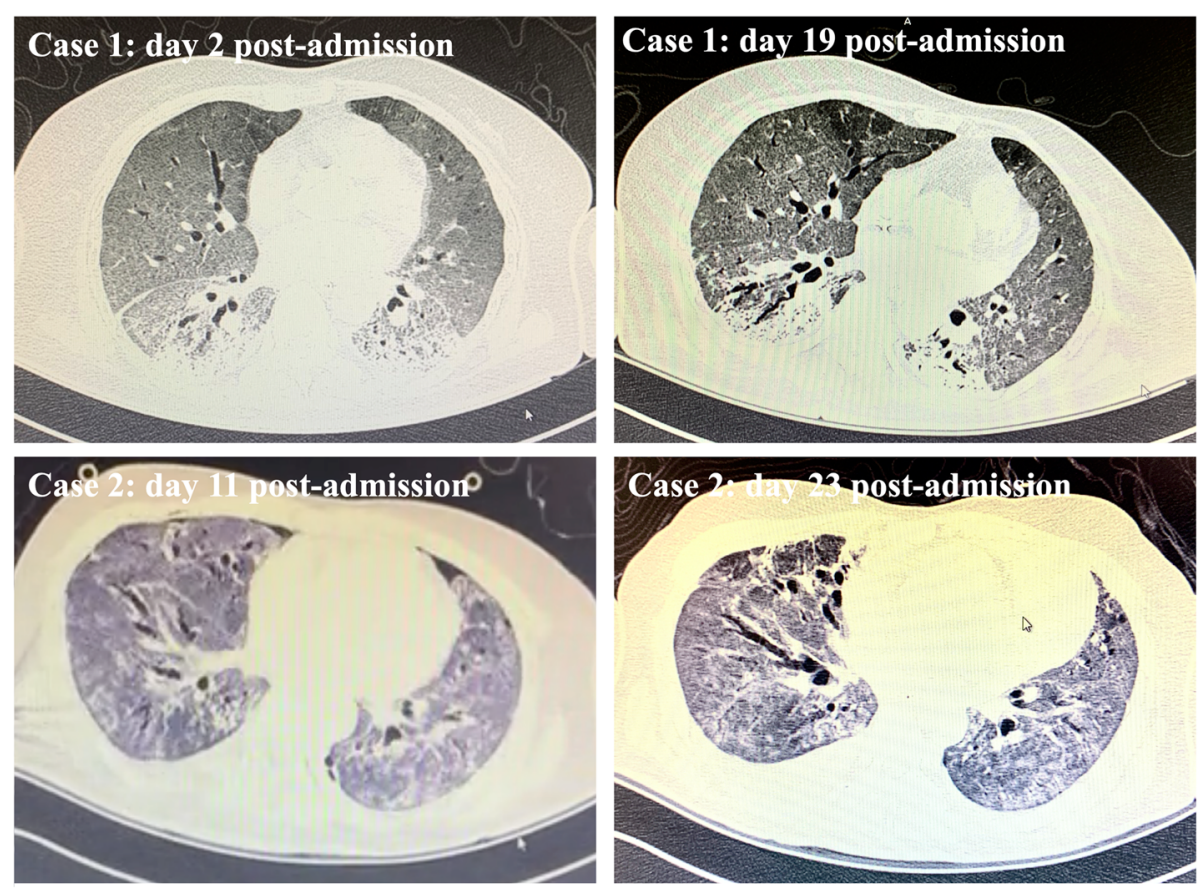

Fig. 1 Left: transverse chest CT images from a 70-year-old female COVID-19 patient showing bilateral diffuse ground glass opacity, interstitial fibrosis, traction bronchiectasis and a small amount of lung consolidation in the dependent lungs on 2 and 19 days after invasive ventilation. Right: transverse chest CT images from a 42-year-old male COVID-19 patient showing bilateral ground glass opacity, interstitial fibrosis, left pleural effusion and traction bronchiectasis on 36 days and 48 days after invasive ventilation

hypermetabolism may explain why these patients experienced more severe respiratory distress and $\mathrm{CO}_{2}$ retention in the late phase of ARDS.

A remarkably increased physiological dead space may be a prominent pathophysiological feature in mechanically ventilated COVID-19 patients recovering from severe ARDS; however, the underlying mechanism remains unclear. It may be related to significant regional ventilation/perfusion heterogeneity [7] due to loss of lung perfusion regulation and hypoxic vasoconstriction [3], pulmonary microthrombosis [8], and increased anatomical dead space from obvious traction bronchiectasis observed on chest CT.

To reduce the risk of ventilator-induced lung injury with high tidal volume $(8-9 \mathrm{ml} / \mathrm{kg})$, we tried to reduce the VT $(6-8 \mathrm{ml} / \mathrm{kg})$ and increase the RR to maintain the MV. However, severe hypercapnia $\left(\mathrm{PaCO}_{2} 98 \mathrm{mmHg}, \mathrm{pH} 7.10\right.$ in case 2) was observed, and the use of sedatives and anesthetic agents had to be increased. These serious consequences are worthy of attention. In these two patients, we set a higher VT $(8-9 \mathrm{ml} / \mathrm{kg})$, lower peak airway pressure $\left(<25 \mathrm{cmH}_{2} \mathrm{O}\right)$, and low PEEP levels $\left(3-6 \mathrm{cmH}_{2} \mathrm{O}\right)$ due to low lung recruitability; barotrauma did not occur. Of course, our experience from few patients cannot be extrapolated to all COVID-19 patients, however, this report provides a possible more suitable lung protective ventilation for COVID-19 patients recovering from acute respiratory failure with refractory hypercapnia, which deserved to be further investigated in clinical research.

In conclusion, during the recovery period of ARDS in mechanically ventilated COVID-19 patients, attention should be paid to the monitoring of physiological dead space and VR [4]. Tidal volume $(8-9 \mathrm{ml} / \mathrm{kg})$ could be increased appropriately under the limited plateau pressure; however, barotrauma should still be considered. In theory, extracorporeal $\mathrm{CO}_{2}$ removal is a better choice for these patients [9] and will be more beneficial to reduce lung injury while awaiting lung tissue repair; however, further clinical investigations are warranted.

\section{Abbreviations}

ARDS: Acute respiratory distress syndrome; Cresp: Respiratory system compliance; COVID-19: Coronavirus disease 2019; CT: Computed tomography; ECMO: Extracorporeal membrane oxygenation; EELV: Endexpiratory lung volume; $\mathrm{FiO}_{2}$ : Fraction of inspired oxygen; $\mathrm{MV}$ : Minute ventilation; $\mathrm{PaCO}_{2}$ : Arterial partial pressure of carbon dioxide;

$\mathrm{P}_{(\mathrm{a}-\mathrm{ET})} \mathrm{CO}_{2}$ : Arterial to end-tidal $\mathrm{CO}_{2}$ difference; $\mathrm{PaO}_{2}$ : Arterial partial pressure of oxygen; PEEP: Positive end-expiratory pressure; R: Airway resistance; RR: Respiratory rate; VDNT: Ratio of dead space to VT; VR: Ventilatory ratio; $\mathrm{VT}$ : Tidal volume; $\mathrm{VO}_{2}$ : Oxygen consumption; $\mathrm{VCO}_{2}: \mathrm{CO}_{2}$ elimination

\section{Acknowledgements}

This work was supported by Zhejiang University special scientific research fund for COVID-19 prevention and control (No. 2020XGZX008); National Key Research and Development Program of China (No. 2016YFC1304300); National Natural Science Foundation of China (No. 81870072); CAMS Innovation Fund for Medical Sciences (No. 2018-12M-1-003) and Non-profit Central Research Institute Fund of CAMS (No. 2019TX320006). 


\section{Authors' contributions}

All authors contributed to the design and conception of the study and performed medical treatment for these two patients; The first draft of the manuscript was written by JX, YF, ML and XY; YZ, JD and QZ revised the manuscript. All authors read and approved the final version of the manuscript.

\section{Funding}

The authors have not received money, gifts, or other compensation from any organization, institution, or business that may be affected financially by our publication.

\section{Availability of data and materials}

Not applicable.

\section{Ethics approval and consent to participate}

The study was approved by the ethics committee of China-Japan Friendship Hospital (2020-21-K16).

\section{Consent for publication}

Both of the patients gave written consent for their personal or clinical details along with any identifying images to be published in this study. A copy of the written consent is available for review by the Editor-in-Chief of this journal.

\section{Competing interests}

The authors declare that they have no competing interests.

\section{Author details}

'Department of Pulmonary and Critical Care Medicine, National Clinical Research Center for Respiratory Diseases, Institute of Respiratory Medicine, Chinese Academy of Medical Sciences, China-Japan Friendship Hospital, No 2, East Yinghua Road, Chaoyang District, Beijing 100029, China. ${ }^{2}$ School of Biological Science and Medical Engineering, Beihang University, Beijing 100191, China. ${ }^{3}$ Department of Surgical Intensive Care Unit, China-Japan Friendship Hospital, Beijing 100029, China.

Received: 30 April 2020 Accepted: 19 August 2020

Published online: 27 August 2020

\section{References}

1. Di Gennaro F, Pizzol D, Marotta C, Antunes M, Racalbuto V, Veronese N, et al. Coronavirus diseases (COVID-19) current status and future perspectives: a narrative review. Int J Environ Res Public Health. 2020;17(8):2690.

2. World Health Organization. https://www.who.int/docs/default-source/ coronaviruse/situation-reports/20200429-sitrep-100-covid-19.pdf?sfvrsn= bbfbf3d1_6 (accessed on 11 March 2020).

3. Gattinoni L, Coppola S, Cressoni M, Busana M, Rossi S, Chiumello D. Covid19 does not Lead to a "typical" acute respiratory distress syndrome. Am J Respir Crit Care Med. 2020;201:1299-300.

4. Liu X, Liu X, Xu Y, Xu Z, Huang Y, Chen S, et al. Ventilatory ratio in Hypercapnic mechanically ventilated patients with COVID-19 associated ARDS. Am J Respir Crit Care Med. 2020;201:1297-9.

5. Pan C, Chen L, Lu C, Zhang W, Xia JA, Sklar MC, et al. Lung Recruitability in SARS-CoV-2 associated acute respiratory distress syndrome: a single-center, observational study. Am J Respir Crit Care Med. 2020;201:1294-7.

6. Henderson WR, Chen L, Amato MBP, Brochard L. Fifty years of research in ARDS. Respiratory mechanics in acute respiratory distress syndrome. Am J Respir Crit Care Med. 2017;196:822-33.

7. Robertson HT. Dead space: the physiology of wasted ventilation. Eur Respir J. 2015:45:1704-16.

8. Nuckton TJ, Alonso JA, Kallet RH, Daniel BM, Pittet JF, Eisner MD, et al. Pulmonary dead-space fraction as a risk factor for death in the acute respiratory distress syndrome. N Engl J Med. 2002;346:1281-6.

9. Goligher EC, Amato MBP, Slutsky AS. Applying precision medicine to trial design using physiology. Extracorporeal $\mathrm{CO} 2$ removal for acute respiratory distress syndrome. Am J Respir Crit Care Med. 2017;196:558-68.

\section{Publisher's Note}

Springer Nature remains neutral with regard to jurisdictional claims in published maps and institutional affiliations.

\section{Ready to submit your research? Choose BMC and benefit from:}

- fast, convenient online submission

- thorough peer review by experienced researchers in your field

- rapid publication on acceptance

- support for research data, including large and complex data types

- gold Open Access which fosters wider collaboration and increased citations

- maximum visibility for your research: over $100 \mathrm{M}$ website views per year

At BMC, research is always in progress.

Learn more biomedcentral.com/submissions 